\title{
Fraud Frevention for Sustainable Social Enterprise Using Participative Social Governance
}

\author{
Rudy Suryanto ${ }^{1}$, Nafsiah Mohammed ${ }^{2}$, Rizal Yaya ${ }^{3}$ \\ \{rdsuryanto@gmail.com ${ }^{1}$, nafsiah793@salam.uitm.edu.my ${ }^{2}$, rizalyaya@gmail.com³ ${ }^{3}$. \\ Muhammadiyah Yogyakarta University, Daerah Istimewa Yogyakarta, Indonesia ${ }^{1,3}$, Universiti Teknologi Mara, \\ 40450 Shah Alam, Selangor, Malaysia ${ }^{2}$
}

\begin{abstract}
Social enterprise is not immune from fraud. As social enterprise is growing, there are some risks of fraud occurrance. Therefore, the purpose of this paper are to discuss types of frauds risks in Indonesian social enterprise and the effective ways to prevent it. This study used case study in one of social enterprise in Indonesia, that is at Panggungharjo, Indonesia. Panggungharjo has Village-owned Enterprise that manage waste management as its social business. The finding of this study indicates that there are three types of fraud occurred in Indonesian social enterprise. These types of fraud could be prevented by engaging community in decision making and monitoring process which are known as participative social governance. This study argue that participative social governence is more effective in fraud prevention rather than external audit and monitoring. The study will be useful for scholars, policy makers and regulators who are interested in Indonesian social enterprise.
\end{abstract}

Keywords: social enterprise, fraud prevention, participative social governance

\section{Introduction}

Social Enterprise is perceived to be more effective and sustainable to tackle complex social issues such as health, education, social and environmental issues. This model is not a new one. The history of social enteprise can be tracked more than 100 years ago, started by Florence Nightingale (Brouard, Hebb, \& Madill, 2008). The development is expected to continously grow (Dees, 1998). Social Enterprise model gained momentum after Muhammad Yunus won Nobel Prize. Social Enteprise model become world wide phenomenon, including in developing countries, such as Indonesia. Traditionally social enterprise works on education and health sector, but now social enteprises entering broader sectors such as waste management, community based tourism and sustainable energy.

Inspired by current trend of Social Enterprise, Indonesia government passed Law No 6/2014 which gave greater responsibility and authority for Village Government to manage its teritory and finance. This law was oto-critic of previous empowerment model which too much emphasize on community driven approach and neglected Village government role. To support the policy, Central Government of Indonesia directly transferred fund to the Village Government, known as Village Fund to be used for various program such as infrastrucure, community empowerment and established Village owned Enterprise. Village owned Enteprise has nature of social enterprise since its ultimate goal is to increase the prosperity of Village people. The prosperity is not only measured by financial indicators but also non financial indicators such as quality of health, education and nature protection.

Since the law of Village enacted on 2014, the number of Village owned Enterprise has been increasing significantly up to 45,459 (Ministry of Village Report, 2018). As the number of Village owned Enterprises grow, so that the risk of frauds. As nascent type of organization in Indonesia Village owned Enterprise has lack of guidance and standards. There were some incident reported to police of wrongdoings indication in Village owned Enterprise. In previous year, Corruption Eradication Commission (KPK) stated that 400 of Village Head convicted of Village Fund misappropriation. Although Village owned Enterprise is a separated organisation, the misconduct send alarming concern on the risk of fraud in Village owned enterprise.

This paper discuss the risk of fraud in Village owned Enterprise based on our observation and interview with management of Village owned Enteprise in Panggungharjo. Panggungharjo is considered one of the best Village owned Enterprise in Indonesia. Panggungharjo design and implement participative social governance that effectively prevent management of Village owned Enterprise to commit fraud. 
This model can be implemented to other Village owned Enterprise and Social Enterprise which operated in rural areas. This paper will be divided into following section. Introduction section will outline the issue and importance of performing Fraud Prevention Program in Social Enterprise. Literature review section will discuss previous research on social enterprise, risk of fraud, fraud prevention program, and participative governance. Method section will discuss about case study we conducted in Panggungharjo. Result and discusion section will discuss about finding and discussion based on our understanding and literature review. Lastly we outline the conclusion, limitation of study and contribution.

\section{Literature Review}

There is no single definition of social enterprise being agreed by scholar. European commission define social enterprise as type of business with social or societal objectives of the common good is the reason for the commercial activity, often in the form of a high level of social innovation (Braunerhjelm \& Hamilton, 2012). EMES (Emergence Social Enterprise in Europe) Network summarise criteria of social enterprise which divided into two : economic dimensions and social dimensions (Defourny et al., 2008). Social entprise has economic dimensions which are ; a continous activity of producing goods and/or selling services, has a high degree of autonomy, has a significant level of economic risk, a minimum amount of paid of work. Social Enteprise also has social dimensions which are; an explicit aim to benefit the commmunity, an initiative launched by a group of citizens, a decision-making power not based on capital ownership, a participatory nature and limited profit distribution.

Social enterprise is a young field of study. Although the practice can be traced back more than one hundred year ago, the research of social enterprise started to emerge in mid 1990s (Defourny et al., 2008). In the beginning the research was concern on explaining the emergence of Social enterprise. Initially, the research focus on individual level, but recently the topic of research is shifting to organizational level. On the organizational level, institutional approach is considered suitable to be a theoritical framework (Mair \& Mart1, 2006). Institutional approach discusses with how relationship among organisation and environment enabling and contraining organizational behaviour (Lawrence et al., 2006). Institution consists of formal such as laws and regulations, and informal insitutions such as customs and traditions (North, 2015). Research findings confirm the influence of formal institutions to social entrepreneurship and commercial entreneurship. However, Pathak \& Muralidharan ( 2016) found that informal institutions namely societal collectivism and societal trust demonstrated positive influence to social entrepreneurship.

One of organisational factor that gain attentions is governance of Social Enterprise. In general governance can be defined as the relationship among various participants in determining decisions of organisation (Low, 2006). In social enterprise the participants involved in decision making do not need to have formal or legal rights to do so. For example the beneficiaries of social enterprise or community member could affect the direction of the social enterprise through social control and public participation.

Social enterprise governance is important for Social Enteprise sustainability. Many researchers concerned whether this model will be sustainable in the long term. Martin \& Osberg stated that social enterprise should manage cost as number of beneficiaries rises to reduce the dependence to govermental and donor support. In doing so, social enterprise should change two features of the existing system, which are actors involved and technology applied. Changing the actors might result changing the governance system.

One of issues that might hampered the sustainability of social enterprise is fraud. Any fraud happened in a social enterprise will give double knock-down. First there might be severe finansial loss, and second the social enterprise will loose public trust. Once social enterprise loose public trust the business is over, since social enteprise is a business of trust. Therefore, we should taking the issues seriously. Entrepreneurs, including sociopreneurs, are rule breakers (Wright \& College, 2011). In the goodway the rule breakers will push innovation in society, but without strong ethics they might breaking the law. Social entrepreneurs might caused significant changes to society. Refer to the institution approach, social enterprise activities run in formal an informal institutions. The formal insitution can be regulated by enacting new law or regulation. But for informal insitutions we need another mechanism to make sure that the innovation carried by social enterprise do not alter the social harmony. There is a risk of financial and non financial loss caused by dysfunctional social enterprise activities(Wright \& College, 2011). 
Literature suggest to promote participatory governance in social enterprise to minimize risk of fraud (Pestoff \& Hulgård, 2016). Participatory governance is important to guard the social mission of social enterprise (Defourny \& Nyssens, 2010). Social enterprise governance also importance in maintain public accountability and prevent mission drift (Ebrahim, Battilana, \& Mair, 2014). Participatory governance also what makes governance in social enterprise different with commercial enterprise.

\section{Research Method}

We used case study in Panggungharjo Village of Yogyakarta, Indonesia. Panggungharjo established Village owned Enterprise which collecting and processing waste from community waste banks. We conducted observations, interviews and focus groups discussions to Village-owned Enterprise management, Head of Village Government, Village Government staff, board of commisioner and beneficiaries. We also done triangulation by checking Village-owned Enterprise documents and interview external party for confirmation.

The study have extensive information on risks of fraud and strategy implemented to prevent fraud in Village-owned Enterprise. We tabulated the data using EMES framework of Social Enterprise. We focus on efforts on organisational level of designing and implementing participative governance for fraud prevention program.

The detailed stages of the study done in four stages as follow:

1. Preliminary investigation: (a) identify the history and background of establishment of Village-owned Enterprise, (b) study the organisation structures and governance

2. Observation, interview and focus groups discussion to identify risk of frauds in Village owned Enterprise

3. Investigate practice of participatory governance as a major strategy to prevent fraud in Villageowned Enterprise

4. Trianggulation and write-up result. Using multi-source of data to formulate model and key factors of successful fraud prevention program using participatory governance.

We measure risks of fraud using risk matrix of concequence and likelihood. We identifiy and score the risk using our understanding of magnitude and likelihood of such risk occured. The score is one until three of low, moderate and high. We then multiply the score of consequence and score of likelihood as risk score. Based on our result we went back to Village-owned Enterprise and Village Government Head and Staff for confirmation and discussion.

\section{Result and Discussion}

Based on our literature review and data collection, we can group risk of frauds in Social Enteprise into three groups. First the misappropriaton of asset, fraudulent in financial reporting and mission camouflage. We found that asset misappropriation is the most likely happened in social enterprise compare with other two.

"risk (in managing social enterprise) do exist. For example the risk of asset misappropriation or abuse of authority (in social enterprise) are alot" Eko Pambudi, Director of Panggung Lestari.

The blurred lines between social mission and commercial mission gave opportunity for management to act not accordance to general principle of internal control. Management could make excuse of any inefficiency or asset misappropriation as part of empowerment. For example, some expenses are over budget due to intention to expand benefeciaries coverage or some irregularities are accepted due to maintain social cohesiveness. Those intentions are goods, but provide loopholes for management to covered up their fraudulent acts.

The second groups risk is fraudulent in financial statement. Fraudulent in financial statement happened when managment purposively understated or overstated figures in financial statement. Social Enterprise must achieve financial and social goals. Financial goals ussually measured by revenue and profit and soial goals measured by coverage of services. To survive the performance evaluation by board, management of Social Enterprise might alter the presentation of financial and non financial reporting to have proper evaluation result.

The last group of risks are mission camuflauge. Mission camuflage is deceiving donor or stakeholder that the activities are for social mission, but the fact is the activities just only for benefit of individual or small groups. The act of deceiving public to have source of fund is a serious risks. As social 
enterprise gain popularity and coverage, many entrepreneurs jump into this model. If their intention is pure this will be very good, but if they do that just for 'marketing gimmick', this will alter social enteprise reputation in general.

Panggunglestari implement some internal controls to prevent and minimise such risk to happen:

Table 1. Summary of Social Enterprise Internal Contol

\begin{tabular}{|c|c|}
\hline No & Control Activities \\
\hline 1 & $\begin{array}{l}\text { Building public trust through transparency on financial reporting ( Panggung Lestari use third } \\
\text { party web based accounting software. Public can see the report and detail of transaction of } \\
\text { each Panggung Lestari Business Unit) }\end{array}$ \\
\hline 2 & $\begin{array}{l}\text { Inviting public participation to monitor the performance and compliance of Panggung Lestari } \\
\text { management, since the Board of Commisioner alone would not sufficient to oversee all of } \\
\text { Panggung Lestari Business Unit. }\end{array}$ \\
\hline 3 & $\begin{array}{l}\text { Preparing business plan to minimise risk of business failure. Before started each business unit, } \\
\text { Panggung Lestari management previously prepared business plan to minimise the risk of } \\
\text { bankruptcy. }\end{array}$ \\
\hline 4 & Always conducting sound and healthy business practice. \\
\hline 5 . & Preparing monthly and weekly plan as guideline for employee to work. \\
\hline 6. & $\begin{array}{l}\text { Implementing level of authority of cash disbursement. Head of Business unit only allowed to } \\
\text { approved below Rp5 million. He/she need to have approva first from director for above } \\
\text { Rp5million spending. }\end{array}$ \\
\hline 7 & $\begin{array}{l}\text { Preparing financial and performance reporting and discuss with Head of Village and Board of } \\
\text { Commisioner each three months. }\end{array}$ \\
\hline
\end{tabular}

Interestingly in preparing for business plan, management of Panggung Lestari do not only present how the business unit will have how much profit, but also how can the business unit give benefit to Village people. How the business unit will give benefit to the Village people is the ultimate goal. Based on our interview, Agus Subagya one of Commisioner explain that board of commisioner have more focus on benefit rather than profit. Based on this condition, how to maintain the balance between pursuing profit and give benefit is the key of social enterprise to have long term sustainability.

"We understand that we need to have cross-subsidy to our customer. We need to understand with whom we are dealing. If we deal with our community member we try our best to deliver our service at reasonable price, but if we are doing business with outsider we do take normal profit". Eko Pambudi, Director of Panggung Lestari.

We also found the risk of cash flow. Social Enterprise tends to perform their business in thin margin. Once there is fluctuation in business, their cashflow management might be severely affected. Manangement of Panggung Lestari always very cautious in spend their fund. They will try to maximise the usage of working capital to short term activities, and rely on Village Government and Local/Central Government support for long term investment. This is important finding since most of Social Enterprise management lack of financial management.

Panggung Lestari management always try to conduct their business in sound and healthy business practice. Although they have some privilige from Village Government, it doesn't means that they can act loose. They have accountability of performance and financial for each three months and yearly. In the Village People General Assembly, the Head of Village must report the benefit and profit of Panggung Lestari within the year. Head of Village will held accountable by public if there is shadowy transactions. General Assembly will have the highest authority to determine whether they will accept the accountability report, approve strategic initiative and pick up social enterprise management. This mechanism is a very effective check and balance process, because even Head of Village will be held accountable if there is anything bad happenned in Panggung Lestari.

Panggung Lestari also have implement some best practice of modern business, such as remuneration, performance evaluation, information systems and participative budgeting and evalution. When we asked this during interview, how the can learn such things, they said that they learn by 
themselves and they also hired profesional and consultants to help them prepared for the documents and SOP.

\section{Conclusion, Limitations, and Contributions}

Based on our finding and discussion we can conclude that there are two level of Social Enterprise management. First is the management of holding/board and management of unit business/operational. The management of businesss unit is the same with management of other type of business. But the management of Social Enterprise holding is very different with commercial business. In the Social Enteprise holding with consist of Head of Village, Board of Commissioner and Management, the discussion is more on how social enterprise can give direct impact and benefit to village people. Once this expectation cannot be met by management, management will be put in dire situation. To avoid this management of social enterprise should maintain balance of multiple stakeholder expectations and profit vs benefit. The failure to achieve such balance will increase the risk of fraudulent of social enterprise financial report. We can learn on how Panggung Lestari management to maintain such balance and lowering the risk of financial fraudulent reporting.

There is also good example on how to increase public awareness and participation to monitor social enterprise financial management. The risk that can lead of social enterprise cannot deliver their service is the risk of cash flow management. The risk of cash flow management is relatively high in social enterprise since they operate in very thin margin. This situation might be worsened by wrong budget allocation. Panggung Lestari can give us example how to tied up business and social goal into business plan dn break it down into operational and weekly plan. By using better planning, Social Enterprise might reduce the risk of cash flow management.

In conclusion there is potential of Panggungharjo model to be implemented to other Villageowned Enterprise or social enterprise operated in rural areas. Engaging communities and local groups are more effective in preventing fraud occured. The risk of reputation and social repudiation are more frightening for Villager compare to formal sanctions.

\section{References}

[1]Braunerhjelm, P., \& Hamilton, U. S.: Social entrepreneurship - a survey of current research. Swedish Entrepreneurship Forum Policy Papers (2012)

[2]Brouard, F., Hebb, T., \& Madill, J.: Development of a social enterprise typology in a Canadian context. pp 1-39. (2008)

[3]Dees, J. G.: Enterprising nonprofits. Vol. 76, pp 54-67. Harvard Business Review (1998)

[4]Defourny, J., Nyssens, M., Birkhölzer, K., Borzaga, C., Fraisse, L., Galera, G., \& Zandonai, F.: Social enterprise in europe: recent trends and developments. Vol. 4, pp 202-228. Social Enterprise Journal (2008)

[5]Defourny, J., \& Nyssens, M.: Conceptions of social enterprise and social entrepreneurship in Europe and the United States: Convergences and divergences. Vol. 1, 32-53. Journal of Social Entrepreneurship (2010)

[6]Ebrahim, A., Battilana, J., \& Mair, J.: The governance of social enterprises: Mission drift and accountability challenges in hybrid organizations. Vol. 34, pp 81-100. Research in Organizational Behavior (2014)

[7]Lawrence, T. B., Institutions, R. S., Stewart, I., Hardy, C., Lawrence, T. B., Nord, W. R., \& Sage, E.: Institution and institutional work. pp 215-254. Thomas Lawrence and Roy Suddaby, (2006)

[8]Low, C.: A framework for the governance of social enterprise. Vol. 33, pp 376-385. International Journal of Social Economics (2006)

[9]Mair, J., \& Mart1, I.: Social entrepreneurship research : A source of explanation, prediction, and delight, Vol. 41, pp 36-44. (2006)

[10]North, D. C.: Institutions. Vol. 5, pp 97-112. (2015)

[11]Pathak, S., \& Muralidharan, E.: Informal institutions and their comparative influences on social and commercial entrepreneurship: the role of in-group collectivism and interpersonal trust. Vol. 54, pp 168188. Journal of Small Business Management (2016)

[12]Pestoff, V., \& Hulgård, L.: Participatory governance in social enterprise. Vol. 27, pp 1742-1759. VOLUNTAS: International Journal of Voluntary and Nonprofit Organizations (2016) 
[13]Wright, M., \& College, I.: The other side of paradise : Examining the dark side of entrepreneurship. Vol. 1. (2011) 